\title{
A study of students' achievement in algebra: Considering the effect of gender and types of schools
}

\author{
Salmiza Saleh ${ }^{1 *} \&$ Muhamad Asyraf Abdul Rahman ${ }^{1}$ \\ ${ }^{1}$ Universiti Sains Malaysia, MALAYSLA
}

\begin{abstract}
Algebra is a branch of mathematics that deals with symbols and also the rules for manipulating those symbols, which are used to represent numbers and quantities in mathematical formulae and equations. It is needed and used in our everyday lives. The purpose of this study was to examine students' performance in algebra related to gender and types of schools. The research sample consisted of 317 students (135 boys and 182 girls) from three types of schools in Malaysia ie; national schools, Islamic-religious schools and boarding schools. Data were collected through an instrument known as the Algebra Achievement Test (AAT), and were then analyzed quantitatively using a two-way ANOVA test. Research findings showed that there were statistically significant main effects for gender and types of schools towards students' achievement in algebra. However, no interactional effects were found between gender and types of schools that could influence the results obtained.It is concluded that gender and types of schools do effect students' achievement in algebra.
\end{abstract}

\author{
Keywords \\ earth, rock, \\ middle school (ages 11-14), \\ vocabulary, \\ discourse

\begin{tabular}{rr}
\hline Received: & 20 Jan 2016 \\
Revised: & 3 Feb 2016 \\
Accepted: & 10 Feb 2016 \\
Published online: & 02 Mar2016 \\
\hline
\end{tabular}

DOI: $10.20897 /$ lectito.201603

\section{INTRODUCTION}

Algebra has always been one of the main subjects in mathematics the world over. This fact is concurred by 65 countries around the world which participated in the Programme for International Student Assessment (PISA), including Malaysia. This is probably due to the fact that algebra is the door to the extension of complex arithmetic articulations, and a progression leap from concrete to abstract concepts in learning mathematics (Skouras 2014). The placement of algebra, as subject of study in mathematics within a school's syllabus, might be different as some countries might offer it in an integrated syllabus, while others might employ it as unified body strands within their mathematics curriculum, like algebra, arithmetic and geometry.

In Malaysia, algebra is integrated into the mathematics syllabus via chapters. It is first introduced to students at the primary school level, and the syllabus progresses into the more comprehensive and advanced stages at the secondary school level. To ensure proficiency in mathematics, students generally have to sit for mathematics classes for at least four to five periods a week. However, regardless of the fairly well thought of syllabus, the Malaysian average mathematics output, as found by the Trends in International Mathematics and Science Study (TIMSS), was still lags far behind other Asian nations such as Japan, Hong Kong, Korea and also Singapore (Mullis et al. 2004). Furthermore, Malaysia has never performed well in mathematics in PISA, and is known as one of the worst performers in 2012, when it ranked below 50, together with countries such as Columbia, Peru and Albania. In addition, the analysis of TIMSS-2007 showed that Malaysia scored the lowest, with only $24 \%$ and 2.1 points, which ranks far below the International Average Score, set at 34\% with 0.3 points, and has to 
settle for the last place, even below Thailand and Indonesia. In the Malaysian context, the condition gets worse, as there is a lack of data for researchers to further investigate the factors affecting mathematics achievement, especially at the secondary school level (Lim \& Saleh 2002; Lim 2003).

This has led to more interest in many parties to investigate students' achievement in mathematics, as the subject has always been correlated with greater chance of employment, better wages and higher on-the-job productivity (Geary \& Hamson 2000). With that reason, it is significantly important to recognize the factors that affect students' mathematics achievement, in order to make good progression and prediction for the future, relating to mathematical decisions. However, this paper will focus only on equity, in relation to two dimensions: gender and types of schools.

\section{LITERATURE REVIEW}

Each student is unique in terms of acquiring knowledge in learning. In terms of results, student performance may be poor, not necessarily because they do not have the skills, but more to the fact that they have not been able to optimize their skills (Bandura 1977). Some said that it is important to measure student achievement in mathematics, as their achievement in high school can have a direct and influential effect on their mathematics performance at the tertiary level (Ismail \& Awang 2007). Furthermore, according to the Centre for the Study of Testing, Evaluation, and Educational Policy (SCTEEP) at Boston College, a test in mathematics is also used to describe students' overall achievement in a non-hierarchical way. Hence, assembling a student's overall results may just be the right kick start needed to assess and elicit a wider range of skills from students, in algebra.

As previously mentioned, it has been found that Malaysian students' achievement, particularly in the subject of mathematics, is on a heavy decline. Analysis showed that in TIMSS-1999, Malaysia was placed $10^{\text {th }}$ out of 38 participating countries, with an average score of 519 points. It was the highest place that Malaysia has ever reached, as it then flunked to $16^{\text {th }}$ out of 46 countries in TIMMS-2003, with an average score of 508 points, before falling down further to $20^{\text {th }}$ place out of 50 participating countries in TIMSS-2007, with a score of 474 points. The downward spiral got worse in TIMSS-2011, when Malaysia stumbled to $26^{\text {th }}$ place with 440 points, and continued its decline in PISA 2012, when it ranked 57th place in mathematics, out of 74 countries which took part in the examination.

It is an irrefutable fact now that Malaysian students are facing a problem in mathematics proficiency, and much can be said about their achievement in mathematics, compared to their counterparts worldwide, and even within neighboring countries. The disparity is obvious, when comparison is made with Singapore, our closest neighbor. Ismail and Awang (2008) found that more than 50 percent of students in Singapore scored higher than the average score of 603 in TIMSS-2003, compared to only 10 per cent of student in Malaysia who managed to do so in the same exam. By comparing the contents tested in TIMSS, such as geometry, measurement, fractions and algebra, researchers found out that Singaporean students have always scored significantly higher than Malaysian students, regardless their gender. Results also showed that girls have always outperformed boys in every area tested, with girls averaging a mean of 53.0, while boys generally hover around the mean of 47.0.

Based on the secondary data of TIMSS-1999, Ismail and Awang (2007) found that there was a significant difference between Malaysian boys' and girls' performance. The research shows that out of 5,577 Malaysian students (girls - 55.2 per cent, boys - 44.4 per cent) involved in TIMSS-1999, aging on average of around 14.4 years old, with a standard deviation of 0.36 , girls outperformed boys in mathematics. Four years later, using the same procedures, Ismail and Awang (2011) once again found out that girls $(M=479.88, S D=75.94)$ still scored better than boys $(M=468.27, S D=80.37)$ in their test. The results were analyzed using data from TIMSS2007, which involved 4,466 students from 150 schools in Malaysia. This finding was consistent with the results obtained from TIMSS-2007 participating countries such as Serbia, Macedonia, Armenia, Moldova, Singapore, Philippines, Cyprus, Jordan and Bahrain (Ismail \& Awang 2008; Mullis et al. 2008) This pattern continuously shows that girls consistently score higher than boys in mathematics in a stable manner, most everywhere around the globe.

Likewise, in the context of students' perceptions towards the mathematics classroom environment and mathematics achievement, Rajoo (2013) also found that girls performed better than boys. Using 445 students as his research sample, Rajoo (2013) found that girls tend to be more involved (more active and joyful) during mathematics lessons, as compared to boys. In relation to that, a study conducted by Abd. Razak, Thien and Darmawan (2014) found that there was also a significant relationship between teachers' gender and eighth grade student achievement in mathematics. In their research entitled "Relationship of Students and Classroom-level Variables with TIMSS 2011 Mathematics Achievement in Indonesia, Malaysia and Thailand", it was found that 
teachers' gender had a significant impact towards eighth grade student achievement in mathematics. Furthermore, when students' scores were correlated with teachers' gender, in the context of Malaysia, the results also showed that female teachers taught better than male teachers. However, unlike the previous studies, Ainuddin Dahlan et al. (2010) found that there was no significant difference between boys and girls achievements in four national schools in Kuala Lumpur, in terms of mathematics results in the LowerSecondary National Examination (PMR).

Besides gender, studies also show that school types also effect students' achievement in mathematics (Lubienski \& Lubienski 2006; Newhouse, 2006; Lubienski, Lubienski \& Crane 2008; Esposito 2010). In the context of Malaysia, there are many different types of schools that have been set up to cater to the different needs and levels of students nationwide. Among the mainstream schools are national schools and national-type of schools (open to all residents, regardless of race, religious beliefs and gender), boarding schools (special school for selected high achievers), and Islamic religious schools (to Muslims who want to learn more about the teaching of Islam). It is a well known fact that boarding school students have always scored high marks in mathematics (particularly in the Malaysian standard examinations) compared to students from other schools (Nordin, et al. 2003). National and national-type rural schools students, on the other hand are generally left behind in terms mathematics achievement (Baharun et al. 2008). As elements in Islam are manifested through various aspects of the educational system (Joseph, 2008), the number of Islamic religious school is also on the rise. However, there is not much research done pertaining this type of school in the country. Although previous studies show that generally, students from religious schools perform better than those from public and private schools (Chubb \& More 1990; Jeyness 2002, 2008; Nordin et al. 2003), this fact cannot yet be corroborated in Malaysia. There is lack of data available in relation to the comparison of students' academic achievement among different types of schools in Malaysian, as the issue is seen as 'sensitive' by the Malaysian Government (Joseph 2006, 2008).

\section{RESEARCH QUESTION}

What are the effects of gender and types of school on student's achievement in algebra?

a. Is there a significant main effect in terms of student's achievement in algebra between boys and girls?

b. Is there a significant main effect in terms of students' achievement in algebra amongst national schools, religious schools and boarding schools?

c. Is there a significant interaction effect between gender and types of schools in terms of students' achievement in algebra?

\section{METHODOLOGY}

This research adopted a survey research design to collect the required data. Purposive sampling technique has been used to select the schools and students. A total of 317 students (see Table 1) from 12 schools (four national schools, four Islamic religious schools and four boarding schools) with the similar status (government aided high performing school) were required to complete a test known as the Algebra Achievement Test (AAT) within 60 minutes, administered during the school hours. The AAT consisted of 30 multiple-choice questions ( 5 questions on knowledge, 17 questions on concept and 8 questions on higher order thinking skills). Data obtained were then analyzed quantitatively using Two-Way ANOVA analysis.

\section{RESULTS}

\section{What are the effects of gender and types of schools on students' achievement in algebra?}

Table 2 shows mean and standard deviation for gender in national schools, religious schools and boarding schools. Table 2 shows that the total mean score for boys $(M=20.73, S D=4.82)$ is lower than the total mean

Table 1. Number of samples for national school, religious school and boarding school

\begin{tabular}{lccc}
\hline Types of schools & Girl & Boy & Total \\
\hline National school & 67 & 39 & 106 \\
Religious school & 59 & 47 & 106 \\
Boarding school & 56 & 49 & 105 \\
Total & 182 & 135 & 317 \\
\hline
\end{tabular}


score for girls $(M=22.02, S D=4.22)$. Regardless of the types of schools, it can be concluded that girls $(N=$ 182) outperform boys $(N=135)$ in algebra achievement in each school.

Table 3 shows results for Levene's test of equality of error variances. The significant $(p)$ value is 0.03 (> 0.01 ), implies that the assumption for homogeneity of variance is not violated. Therefore, it can be said that each school and gender has equal variance in the mean scores of algebra.Table 4 shows results for the test of between-gender and types of schools effect.

Is there a significant main effect in terms of students' achievement in algebra between boys and girls?

Alternative hypothesis: There is a significant difference in terms of students' achievement in algebra

between boys and girls.

Table 4 shows that there is a statistically significant main effect for gender $[F(1,311)=10.83, p=0.00]$. Although the effect size for gender is small, with eta squared value 0.03 (Cohen, 1988), it gives significant impact to a large sample (in this case, $N=317$ ) (Pallant 2001). Thus, the alternative hypothesis cannot be rejected due to the $p$-values results $(0.00<0.01)$. Hence, there is a significant main effect in terms of students' achievement in algebra between boys and girls.

Is there a significant main effect in terms of students' achievement in algebra amongst national schools, religious schools and boarding schools?

Alternative hypothesis: There is a significant difference in terms of students' achievement in algebra amongst national schools, religious school and boarding school.

Table 4 shows that there is a statistically significant main effect for schools $[F(2,311)=25.57, p=0.00]$. The effect size for schools is considered as large (eta squared $=0.14$ ). Thus, the alternative hypothesis cannot be rejected due to the $p$-values results $(0.00<0.01)$. Hence, there is a significant main effect in terms of students' achievement in algebra amongst national schools, religious schools and boarding schools.

Table 2. Mean and standard deviation for gender in national schools, religious schools and boarding schools

\begin{tabular}{llccc}
\hline Gender & School & Mean & Std. Deviation & $\mathrm{N}$ \\
\hline Boy & National school & 18.72 & 4.40 & 39 \\
& Religious school & 20.36 & 4.32 & 47 \\
& Boarding school & 22.67 & 4.95 & 49 \\
& Total & 20.73 & 4.82 & 135 \\
\hline Girl & National school & 20.10 & 4.60 & 67 \\
& Religious school & 21.88 & 3.46 & 59 \\
& Boarding school & 24.46 & 3.17 & 56 \\
& Total & 22.02 & 4.22 & 182 \\
\hline Total & National school & 19.59 & 4.56 & 106 \\
& Religious school & 21.21 & 3.92 & 106 \\
& Boarding school & 23.63 & 4.17 & 105 \\
& Total & 21.47 & 4.53 & 317 \\
\hline
\end{tabular}

Table 3. Levene's Test of Equality of Error Variances

\begin{tabular}{cccc}
\hline $\mathrm{F}$ & $\mathrm{df} 1$ & $\mathrm{df} 2$ & $\mathrm{Sig}(\mathrm{p})$ \\
\hline 2.52 & 5 & 311 & .03 \\
\hline
\end{tabular}

*The mean difference is significant at 0.01 level

Table 4. Tests of between-gender and types of schools effect

\begin{tabular}{lcccccccc}
\hline Source & $\begin{array}{c}\text { Types III Sum of } \\
\text { Squares }\end{array}$ & Df & Mean Square & F & Sig. & $\begin{array}{c}\text { Partial Eta } \\
\text { Squared }\end{array}$ & $\begin{array}{c}\text { Noncent. } \\
\text { Parameter }\end{array}$ & $\begin{array}{c}\text { Observed } \\
\text { Power }\end{array}$ \\
\hline Corrected Model & 1061.08 & 5 & 212.22 & 12.20 & .00 & .16 & 60.98 & 1.00 \\
Intercept & 140410.29 & 1 & 140410.29 & 8068.83 & .00 & .96 & 8068.83 & 1.00 \\
Gender & 188.47 & 1 & 188.47 & 10.83 & .00 & .03 & 10.83 & .76 \\
School & 889.84 & 2 & 444.92 & 25.57 & .00 & .14 & 51.14 & 1.00 \\
Gender * School & 2.17 & 2 & 1.09 & .06 & .94 & .00 & .13 & .01 \\
Error & 5411.89 & 311 & 17.40 & & & & & \\
Total & 152598.00 & 317 & & & & & & \\
Corrected Total & 6472.97 & 316 & & & & & &
\end{tabular}


Is there a significant interaction effect between gender and types of schools in terms of students' achievement in algebra?

Alternative hypothesis: There is an interaction effect in terms of students' achievement in algebra between gender and types of schools.

Table 4 shows that there is no statistically significant interaction effect gender*schools $[F(2,311)=.06, p$ $=0.94]$. The profile plot is shown in Figure 1. Therefore, the alternative hypothesis is rejected $(p$-value $=0.94$ $>0.01)$. It can be concluded that there is no interaction effect in terms of students' achievement in algebra between gender and types of schools.

Estimated Marginal Means of Algebra Score

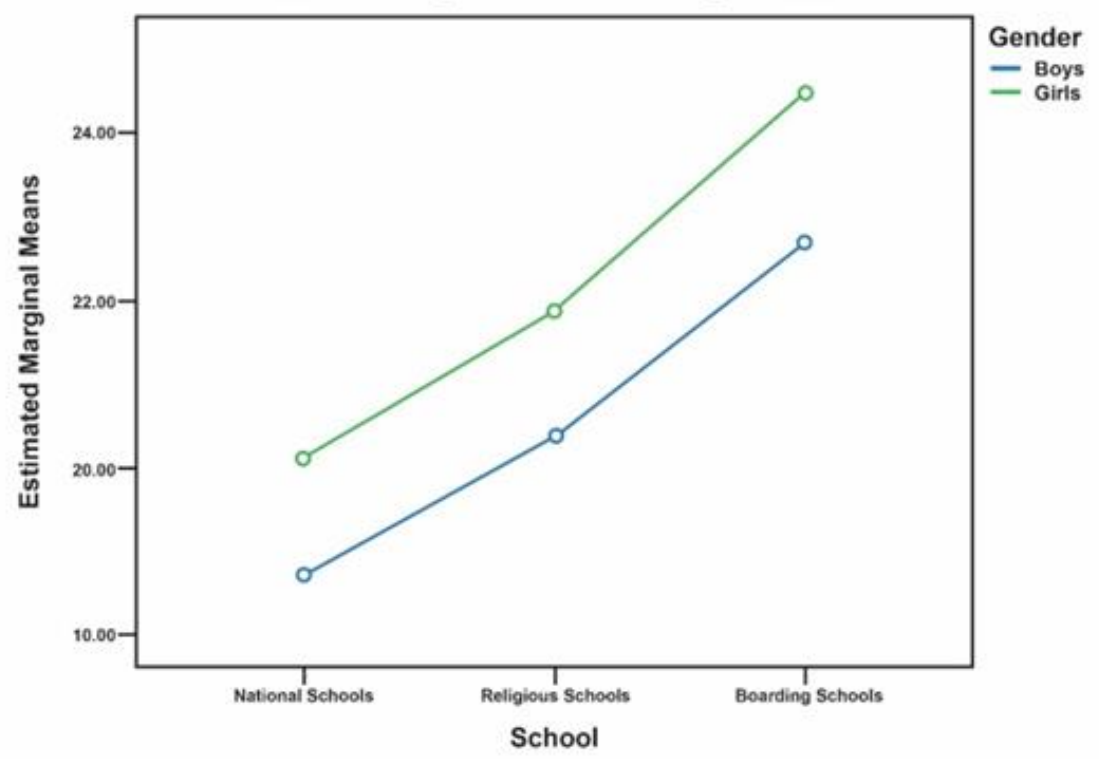

Figure 1. Profile plot for interaction effect between gender and types of schools

\section{DISCUSSION}

The results show that boarding schools' students (both boys and girls) outperform Islamic religious schools' and national schools' students in algebra achievement. Boarding schools' students obtain the highest mean score in the test administered, followed by Islamic religious schools' students and national schools' students. This may be due to the reason that boarding schools generally induct the best students and offer the most conducive learning environment, compared to the Islamic religious schools and national schools. Compared to national schools, the Islamic religious schools also take in better students and present a more conducive learning environment than national schools.

On the overall, it was found that girls $(M=22.02, S D=4.22)$ outperform boys $(M=20.73, S D=4.82)$ in terms of achievement in algebra, in all types of schools. Results obtained are parallel with the findings of Ismail and Awang (2007, 2012), Alkhateeb (2001), the US Department of Education, National Center for Education Statistic (2001), Mullis et al. (2008) and Rajoo (2013). However, the results are inconsistent with the findings of the American Institute of Research (2005), which found that boys perform better in things related to application problems.

The results are also in line with Freeman's (2005) findings, in which girls are found to develop greater confidence in their abilities to adopt with mathematical concepts and merge well with curriculum and assessment methods. Boys seem to understand the concepts of algebra faster than girls. However, girls often outperform boys as they tend to immerse themselves in practices and homeworks in order to polish their understanding about abstract concepts. Moreover, boys generally seem to view that doing homework as nonmasculine-like (or feminine-like), and thus explains the reason why girls tend to become more superior in algebra, as compared to boys (Ainuddin Dahlan et al. 2010).

Moreover, this research finding is correlated with the research done by Ainuddin Dahlan et al. (2010), which found that even though boys have advantages in spatial and mathematical abilities, girls have always been consistent in adopting themselves with the curriculum. Besides, girls can most often tolerate lengthy lectures 
(traditional approach) given by the teacher, as the lower level of testosterones in their body makes it possible for them to adopt with this type of instruction, and as a result, excel more in mathematics. Compared to boys, girls also favor learning that involves solving problems related to real world situations, thus making them perform better in examinations.

Apart from that, girls also seem to outperform boys because the teacher-gender ratio is imbalanced at schools in Malaysia. Research by Abd. Razak, Thien and Darmawan (2014) showed that students who were taught by female teachers scored higher in eighth grade mathematics test, compared to those who were taught by male teachers. At the moment, according to the Educational Management Information System [EMIS] (2014), there is a huge gap between female teachers $(127,030)$ and male teachers $(55,385)$ at the secondary school level in Malaysia. This explains the reason for the learning style and curriculum at schools, which is more female-biased, where the interaction effect between teacher-gender and students' achievement has been found significant (Dee, 2006). On the contrary, the current findings also disagree with the research findings by Antecol, Eren and Ozbeklik (2012), which found that female teachers will lead to poorer results in mathematics among girls, not boys.

\section{CONCLUSION AND IMPLICATION}

This study has found that there is (i) a significant main effect in terms of students' achievement in algebra between boys and girls, (ii) a significant main effect in terms of students' achievement in algebra amongst national schools, religious schools and boarding schools, and (iii) no interaction effect in terms of students' achievement in algebra between gender and types of schools.

The findings of this study provide direct implications on the implementation of mathematics education in Malaysia, especially at the secondary level. There are several things that can be addressed in the context of student interest in mathematics. The Malaysian Ministry of Education (MOE) policy-makers should focus on the fair distribution of educational resources, particularly for the national and Islamic religious schools. Undoubtedly, teachers must also have the credibility and the responsibility to educate mathematics as equally fair as they can, without being biased towards any gender. And, ultimately, the school environment should also be cultivated towards fostering students' interest in mathematics more, as the benefits of this far outweigh other types of improvements for the students' future in the real world. Conclusively, the implications of this research could serve as referral data for the Malaysian Ministry of Education (MOE), to enable them to better monitor the gaps in terms of students' mathematics achievement amongst national schools, religious schools and boarding schools. Furthermore, educators should also be more creative and active in teaching mathematics, to ensure a more meaningful and fruitful participation of both boys and girls in learning process. Genderimbalance in achievement at schools, if not remedied properly, may contribute to a wide gender gap, especially in terms of university enrollment, at the tertiary level.

\section{REFERENCES}

Abd Razak, N., Thien, L.M., \& Darmawan, I.G.N., 2014. 'Relationship of student-and classroom-level variables with TIMSS 2011. Mathematics achievement in Indonesia, Malaysia and Thailand'. In TIMSS 2011: What can we learn together? Reaching greater heights by Ong, S. L et al., (2014). SEAMEO RECSAM.

Alkhateeb, H.M., 2001. Gender differences in mathematics achievement among high school students in the United Arab Emirates, 1991-2000. School Science and Mathematics, 101(1), pp.5-9.

Antecol, H., Eren, O. and Ozbeklik, S., 2012. The effect of teacher gender on student achievement in primary school: evidence from a randomized experiment. The Institute for the Study of Labor (IZA), USA

Azina, I.N. and Halimah, A., 2012. Student factors and mathematics achievement: Evidence from TIMSS 2007. Eurasia Journal of Mathematics, Science and Technology Education, 8(3), pp.249-255.

Baharun, N., Ahmad, N. and Arul, E., 2008. Kajian perbandingan pencapaian matematik pelajar bandar dan luar bandar peringkat Penilaian Menengah Rendah (PMR).

Bandura, A 1977. Social learning theory. Englewood Cliffs, NJ: Prentice Hall.

Chubb, J.E. and Moe, T.M., 2011. Politics, markets, and America's schools. Brookings Institution Press.

Chudowsky, N. and Chudowsky, V., 2009. State Test Score Trends through 2007-08, Part 4: Has Progress Been Made in Raising Achievement for Students with Disabilities?. Center on Education Policy.

Cohen, J., 1988. Statistical Power Analysis for the Behavioral Sciences. (2nd ed.). Hillsdale, New Jersey: L.

Coleman, J.S., 1966. Equality of educational opportunity. Washington, D.C: U.S. Government Printing Office

Craig, L., 2010. School type and mathematics achievement: A comparison of magnet and public secondary schools using the educational longitudinal study of 2002 data set. Available at http://digitalcommons.goodwin.edu/oie_pubs/1 
Dahlan, N.A., Noor, N.A.M., Mustafa, S.M.S., Hashim, K.S. and Zulkifli, V., 2010. Exploring the Gender Gap in Achievement in Malaysia: A Case for Learning Styles. International Journal of Learning, 17(4).

Dee, T.S., 2007. Teachers and the gender gaps in student achievement.Journal of Human Resources, 42(3), pp.528-554.

Educational Management Information System [EMIS], 2014. Teacher-gender ratio statistics for secondary school in Malaysia. Available at: http://emisportal.moe.gov.my

Freeman, J., 2005. Permission to be gifted: How conceptions of giftedness can change lives. In R. Sternberg \& J. Davidson, Conceptions of giftedness. Cambridge: Cambridge University Press.

Gallagher, A.M. and Kaufman, J.C., 2005. Integrative conclusion in gender differences. In: Gallagher and Kaufman (Eds.), Mathematics: An integrative psychological approach. Cambridge: Cambridge University Press.

Geary, D.C., Hamson, C.O. and Hoard, M.K., 2000. Numerical and arithmetical cognition: A longitudinal study of process and concept deficits in children with learning disability. Journal of experimental child psychology, 77(3), pp.236-263.

Ghagar, M.N.A., Othman, R. and Mohammadpour, E., 2011. Multilevel analysis of achievement in mathematics of Malaysian and Singaporean students. Journal of Educational Psychology and Counseling, 2, pp.285-304.

Ginsburg, A., Leinwand, S., Anstrom, T. and Pollock, E., 2005. What the United States Can Learn From Singapore's World-Class Mathematics System (and What Singapore Can Learn from the United States): An Exploratory Study. American Institutes for Research.

Ibrahim, R., 2007. Multiculturalism and education in Malaysia. Culture and Religion, 8(2), pp.155-167.

Ismail, N.A. and Awang, H., 2008. Differentials in mathematics achievement among eighth-grade students in Malaysia. International Journal of Science and Mathematics Education, 6(3), pp.559-571.

Ismail, N.A. and Awang, H., 2009. Mathematics Achievement among Malaysian Students: What Can They Learn from Singapore?. International Education Studies, 2(1), pp. 9-17

Jeynes, W., 2000. Assessing school choice: A balanced perspective. Cambridge Journal of Education, 30(2), pp.223-241.

Jeynes, W.H., 2008. The effects of Catholic and Protestant schools: A meta-analysis. Journal of Catholic Education, 12(2), p. 258-278.

Jeynes, W.H., 2002. Why religious schools positively impact the academic achievement of children. International Journal of Education and Religion, 3(1), pp.16-32.

Jeynes, W.H., 2001. Religious commitment and adolescent behavior.Journal of interdisciplinary Studies, 13(1/2), pp.31-50.

Joseph, C., 2003. Theorisations of Identity and Difference: Ways of being Malay, Chinese and Indian schoolgirls in a Malaysian secondary school(Doctoral dissertation, Monash University, Faculty of Education).

Joseph, C., 2006. Negotiating discourses of gender, ethnicity and schooling: ways of being Malay, Chinese and Indian schoolgirls in Malaysia. Pedagogy, Culture \& Society, 14(01), pp.35-53.

Joseph, C., 2008. Ethnicities and education in Malaysia: Difference, inclusions and exclusions. In The Education of Diverse Student Populations(pp. 183-208). Springer Netherlands.

Joseph, F., Hair, Jr., William, C. Black, Barry J.B., Rolph E.A. and Ronald L.T., 2006. Multivariate data analysis (Rev.ed.). Pearson Education International.

Kalaivani, K. and Ahmad Tarmizi, R., 2014. Assessing thinking skills: a case of problem-based learning in learning of algebra among Malaysian form four students. Journal of International Academic Research for Multidisciplinary, 2(3), pp.166173.

Lim, C.S., 2002. The culture of mathematics learning in two Chinese primary schools: Drill and practice. Paper presented at the Invitational Conference on Values in Mathematics and Science Education 2002 at Monash University from 35 October 2002.

Lim, C.S., 2003. The culture of mathematics learning in two Chinese primary schools: Drill and practice. Philosophy of Mathematics Education Journal, 17.

Lubienski, S.T. and Lubienski, C., 2006. School sector and academic achievement: A multilevel analysis of NAEP mathematics data. American Educational Research Journal, 43(4), pp.651-698.

Lubinski, D., Webb, R.M., Morelock, M.J. and Benbow, C.P., 2001. Top 1 in 10,000: a 10-year follow-up of the profoundly gifted. Journal of applied Psychology, 86(4), p.718-729.

Lubienski, C. and Lubienski, S.T., 2006. Charter, private, public schools and academic achievement: New evidence from NAEP mathematics data (Vol. 16). New York: National Center for the Study of Privatization in Education, Teachers College, Columbia University.

Lubienski, S.T., Lubienski, C. and Crane, C.C., 2008. Achievement differences and school type: The role of school climate, teacher certification, and instruction. American Journal of Education, 115(1), pp.97-138.

Morse, S., 1998. Separated by sex: A critical look at single-sex education for girls. American Association of University Women. Washington, DC

Mullis, I.V., Martin, M.O., Gonzalez, E.J. and Chrostowski, S.J., 2004.TIMSS 2003 International Mathematics Report: Findings from IE $A$ 's Trends in International Mathematics and Science Study at the Fourth and Eighth Grades. TIMSS \& PIRLS International Study Center. Boston College, 140 Commonwealth Avenue, Chestnut Hill, MA 02467.

Mullis, I.V., Martin, M.O., Foy, P. and Arora, A., 2012. TIMSS 2011 international results in mathematics. International Association for the Evaluation of Educational Achievement. Herengracht 487, Amsterdam, 1017 BT, The Netherlands. 
Murugan, A. and Rajoo, L., 2013. Students' perceptions of mathematics classroom environment and mathematics achievement: A Study in Sipitang, Sabah, Malaysia. International Conference on Social Science Research, Penang, Malaysia.

Nordin, A.B., Saad, N.S. and Tajudin, M., 2006. Pencapaian dan Penguasaan Konsep dalam Matematik Peringkat SPM.

OECD, 2014. PIS A 2012 results: What students know and can do - student performance in mathematics, reading and science (Volume I, Revised edition, February 2014), PISA, OECD Publishing. Available from: http://dx.doi.org/10.1787/9789264201118-en

Ogundokun, M.O. and Adeyeno, D.A., 2010. 'Emotional intelligence and academic achievement: The moderating influence of age, intrinsic and extrinsic motivation', The African Symposium: An Online Journal of the African Educational Research Network, 10(2), pp. 127-141.

Pallant, J., 2001. SPSS survival manual. Open University Press, Phiadelphia, USA.

PISA, 2003. OECD Programme for International Student Assessment (PISA). Available at: http://www.pisa.oecd.org/

Skouras, A.S., 2014. Factors associated with middle-school mathematics achievement in Greece: the case of algebra. International Journal of Mathematical Education in Science and Technology, 45(1), pp.12-34.

U.S. Department of Education, National Center for Education Statistics. Digest of Education Statistics, 2001. NCES 2002-130. (Thomas D. Snyder. Production Manager, Charlene M. Hoffman.). Washington, DC.

Zakaria, E., Zain, N.M., Ahmad, N.A. and Erlina, A., 2012. Mathematics anxiety and achievement among secondary school students. American Journal of Applied Sciences, 9(11), p.1828-1832. 